\title{
The anti-diabetogenic effect of essential fatty acid deficiency in multiple low-dose streptozotocin-treated mice persists if essential fatty acid repletion occurs outside of a brief window of susceptibility
}

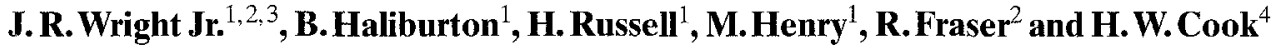 \\ ${ }^{1}$ Department of Pathology, Izaak Walton Killam Children's Hospital, ${ }^{2}$ Department of Pathology and ${ }^{3}$ Department of Surgery, \\ Dalhousic University Faculty of Medicine, and ${ }^{4}$ Atlantic Research Centre for Mental Retardation, Halifax, Nova Scotia, Canada
}

\begin{abstract}
Summary. We have previously shown that essential fatty acid deficiency prevents diabetes mellitus and ameliorates insulitis in multiple low-dose streptozotocin-treated male CD-1 mice and that repletion with $99 \%$ pure methyl linoleate 3 days after the last injection causes diabetes. In the present study, we examined whether repletion of low-dose streptozotocin-treated deficient mice will cause diabetes whenever repletion occurs. Essential fatty acid deficiency was induced by dietary manipulation and was confirmed biochemically. Groups of deficient mice were repleted $6 \mathrm{~h}$, 1 week, 2 weeks, 4 weeks and 8 weeks after the last low-dose streptozotocin treatment; the incidence of diabetes (i.e., non-fasting plasma glucose levels $>11.2 \mathrm{mmol} / 1$ ) and group mean plasma glucose levels were $93 \%$ (19.4 mmol/ 1$), 37 \%$ $(14.8 \mathrm{mmol} / \mathrm{l}), 40 \%(13.7 \mathrm{mmol} / 1), 20 \%(9.0 \mathrm{mmol} / 1)$, and
\end{abstract}

$8 \%(7.8 \mathrm{mmol} / \mathrm{l})$ respectively. The incidence and mean glucose levels for low-dose streptozotocin-induced control chow-fed and non-repleted essential fatty acid deficient CD-1 mice were $100 \%(30.2 \mathrm{mmol} / 1)$ and $0 \%(4.2 \mathrm{mmol} / \mathrm{l})$. The incidence and severity of insulitis also decreased with increasing repletion intervals. These results demonstrate a brief window of susceptibility of less than 8 weeks duration during which repletion will initiate an autoimmune response directed at low-dose streptozotocin-induced Beta-cell neoantigens in low-dose streptozotocin-treated essential fatty acid deficient mice.

Key words: Type 1 (insulin-dependent) diabetes mellitus, autoimmunity, insulitis, low-dose streptozotocin, essential fatty acid deficiency.
Streptozotocin (2-deoxy-2-[3'-methyl-3'-nitrosoureido]D-glucopyranose), a methylnitrosourea with a 2-substituted glucose, is a drug widely used to induce experimental diabetes mellitus [1]. When the drug is given in one large i. v. dose, Beta-cell necrosis and severe diabetes occur within $48 \mathrm{~h}$ in the absence of significant inflammation. In 1976, Like and Rossini [2] reported that multiple subdiabetogenic intraperitoneal doses of streptozotocin result, instead, in a lymphocytic infiltration into the islets (i.e., insulitis) followed by a more gradual onset of severe diabetes.

Diabetes in low-dose streptozotocin (LDS)-treated mice shares many features with Type 1 (juvenile-onset) diabetes in man; both are multifactorial diseases involving genetic, environmental, and autoimmune components. In the LDS model, susceptibility to insulitis is associated with the mouse major histocompatibility complex suggesting a genetic component $[3,4]$. An autoimmune component is documented by the insulitis and by studies showing that various immunosuppressive regimens ameliorate or prevent diabetes $[1,5]$. Because LDS is necessary to initiate the autoimmune response and because its onset is tempo- rally associated with an induction of retrovirus proliferation within Beta cells, an environmental component is apparent $[2,6,7]$.

We have demonstrated that essential fatty acid (EFA) deficiency prevents diabetes in male CD-1 mice given LDS [8]. In that study, 19 of 19 LDS-treated mice on control chow developed diabetes (mean plasma glucose levels $21.6 \mathrm{mmol} / \mathrm{l})$; 1 of 13 LDS-treated mice on the EFA deficient (EFAD) diet developed mild diabetes (mean glucose $7.2 \mathrm{mmol} / \mathrm{l}$ ). EFA deficiency also markedly decreased the severity of the insulitis. In the LDS-treated mice on the control diet, there was severe insulitis with lymphocytic infiltration into the islets and Beta-cell necrosis. In LDS-treated EFAD mice, there was focal mild peri-insulitis with preservation of Beta cells. The finding that EFA deficiency protects from diabetes and insulitis has been replicated in $\mathrm{BB}$ Wistar rats, a strain that develops spontaneous diabetes [9-11]. It is possible that EFA deficiency has a generalized protective effect against autoimmune endocrine disease. BB rats also develop a high incidence of spontaneous thyroiditis at the time of onset of diabetes [12]. We also found that EFA deficiency 
protected the rats from thyroiditis (unpublished observation). For the purpose of elucidating the mechanism of the protective effect of EFA deficiency, we believe that the LDS model is superior to the BB rat because it is inexpensive and the natural history of the disease is about 3 months shorter.

We have previously shown that EFA repletion with intraperitoneal injections of $99 \%$ pure linoleic acid methyl ester 3 days after the last LDS injection resulted in diabetes in four of four LDS-treated EFAD mice [8]. In the present study we have examined whether a window of susceptibility exists or whether a LDS-modified Beta cell will be destroyed whenever EFA supplementation occurs.

\section{Materials and methods}

\section{Induction of EFA deficiency, insulitis, and diabetes}

Male virus antibody free weanling CD-1 mice (Charles River, Montreal, Canada) were housed five per cage and fed either standard laboratory animal chow (Agway Prolab 3000 Formula; Syracuse, NY, USA) or a chow deficient in essential fatty acids (Purina 5803C low essential fatty acid purified diet, Purina Test Diets, Richmond, Ind., USA) ad libitum for 2 months. Our analysis revealed less than $0.25 \%$ fat and $5 \mu \mathrm{g}$ linoleate per g of EFAD chow compared to $6 \%$ fat and $3.2 \mathrm{mg}$ linoleate per $\mathrm{g}$ of control chow; only trace amounts of arachidonate were found in either diet. Murine EFA deficiency was confirmed as described below. Mice on standard chow provided agematched controls for all experiments utilizing EFAD mice.

Mice were weighed and ear notched. Low-dose streptozotocin (Upjohn, Kalamazoo, Mich., USA) was administered i.p. at a dose of $40 \mathrm{mg} / \mathrm{kg}$ per day on experimental days $1,2,3,4$, and 5 (note that all references to days in this study will be referred to numerically with LDS administered on days 1-5; day 6 would be the first day after termination of LDS administration, day 7 the second, etc.). Mice were retroorbitally bled and tested for hyperglycaemia two or three times per week. Plasma glucose levels were determined by the glucose oxidase method using a Beckman glucose analyser (Fullerton, Calif., USA). Diabetes was defined as non-fasted plasma glucose levels $>11.1 \mathrm{mmol} / \mathrm{l}$. Mice were killed at the end of the various experiments and the pancreata were removed, fixed in Bouin's solution, and processed for light microscopy. Sections were stained either with haematoxylin and eosin ( $\mathrm{H} \& \mathrm{E})$ or with aldehyde fuschin (AF), a histochemical reaction for insulin in Beta cell granules.

\section{EFA repletion studies}

To determine whether repletion of LDS-treated EFAD mice with control chow is as diabetogenic as linoleate injections, CD-1 mice were divided into four groups of seven mice per group. All four groups received LDS treatments on days $1-5$. Group 1 received control chow and Group 2 received EFAD chow throughout the whole experiment. EFAD mice in Group 3 were repleted with injections of $99 \%$ pure linoleic acid methyl ester $(100 \mu \mathrm{l}$ per mouse per day $\times 5$ days per week) beginning on day 6 ; EFAD mice in Group 4 were changed to control chow on day 6 . The incidence and prevalence of diabetes were determined; the mice were then killed and their pancreata examined for insulitis. EFA deficiency was confirmed in three randomly chosen mice in Group 2 as described below.

Based on our observation of near identical frequency and severity of diabetes in linoleate-repleted and chow-repleted EFAD mice (described below), we were able to utilize chow-repletion rather than the expensive and labour-intensive daily linoleate injections for our repletion time-course study. CD-1 mice were divided into 7 groups of 20; all mice received LDS treatment on days 1-5. Group 1 received control chow throughout the whole experiment (positive control); Group 2 received EFAD chow throughout the entire experiment (negative control). EFAD mice in groups $3,4,5,6$, and 7 were repleted $6 \mathrm{~h}, 1$ week, 2 weeks, 4 weeks, or 8 weeks, respectively, after the last LDS injection. The incidence and prevalence of diabetes were determined for 21 days after changing from EFAD to control diet and then the mice were killed and their pancreata examined for insulitis. EFA repletion was confirmed from plasma samples as described below. Results were analysed by analyses of variance with paired comparisons as explained in detail in a previous study [13].

\section{Measurement of plasma fatty acids}

Aliquots of plasma (25-250 $\mu \mathrm{l}$, depending on availability of sample) were directly derivitized according to the method of Moser and Moser [14]. Briefly, an internal standard mixture of nonadecanoic (19:0) and heptacosanoic (27:0) acid was mixed with the sample; next, $200 \mu \mathrm{l}$ of fresh acetyl chloride was added dropwise with mixing followed by heating at $75^{\circ} \mathrm{C}$ for $1 \mathrm{~h}$. After cooling, $4 \mathrm{ml}$ of $7 \%$ potassium carbonate was added and the mixture was extracted with $2 \mathrm{ml}$ hexane. After washing with acetonitrile, the hexane was dried under nitrogen at $37^{\circ} \mathrm{C}$ and the fatty acid methyl esters were suspended in carbon disulphide.

Gas chromatography was performed as described previously by Thomas et al. [15]. Aliquots were injected on a $30 \mathrm{~mm} \times 0.25 \mathrm{~mm}$ (internal diameter) fused silica column coated with SP-2330 (Supelco, Oakville, Ontario, Canada). Methyl esters were separated by running the Hewlett-Packard model 5890 II gas chromatograph isothermally at $195^{\circ} \mathrm{C}$ with injector and detector temperature of $250^{\circ} \mathrm{C}$. The column head pressure was $14 \mathrm{kPa}$, linear flow rate was $22 \mathrm{~cm} / \mathrm{s}$, and split ratio was 30:1. The signal from the flame ionization detector was collected and analysed using a Maxima 820 Chromatography Workstation (Millipore-Waters, Mississauga, Ontario, Canada).

Although the presence or absence of EFA deficiency was confirmed biochemically in our EFAD mice by random sampling rather than by testing every mouse, dermatitis and, at autopsy, hepatic fatty change characteristic of EFA deficiency were seen in all EFAD mice and were not seen in control chow-fed or repleted EFAD mice.

\section{Histopathological evaluations}

Histological sections of each pancreas were evaluated "blindly" by an independent reviewer (R.F.) not involved in any other aspect of the study. The reviewer was asked to grade each pancreas independently for both lymphocytic infiltration, using only the $\mathrm{H} \& \mathrm{E}$ section, and for Beta-cell degranulation, using only the AF stain.

$H \& E$ sections of all pancreata were evaluated for insulitis; each pancreas was graded and placed into one of the following categories: (0) normal (i.e., no inflammation), (1) peri-ductal lymphocytic infiltrate (i. e., lymphocytic infiltrate at ductal pole of islet only), (2) periinsulitis (i.e., lymphocytic infiltrate surrounding but not invading islets), (3) insulitis (i.e., lymphocytic infiltrate invading islets), (4) severe insulitis (massive lymphocytic infiltrate with islet destruction). Pancreata were graded for insulitis on the basis of the most severely involved islet in each pancreas.

After an interval of several weeks (and without access to his insulitis scores), the same reviewer was asked to grade all pancreata for degree of Beta-cell degranulation, using only AF-stained sections, as follows: (0) normal, (1) mild degranulation, (2) moderate degranulation, (3) severe degranulation, or (4) absence of granulated Beta cells. Once graded, each AF slide was reviewed a second time and compared to all other slides placed within the same category and any discrepancies were corrected.

Each pancreas was then given a total score based on the sum of the individual insulitis and degranulation grades. Mean total scores 
Table 1. Fatty acid analysis of plasma from CD-1 mice on control and essential fatty acid deficient diets

\begin{tabular}{|c|c|c|c|c|c|}
\hline & $n$ & $\begin{array}{l}18: 1 \\
\text { wt \% }\end{array}$ & $\begin{array}{l}18: 2 \\
\text { wt } \%\end{array}$ & $\begin{array}{l}20: 3 \\
w t \%\end{array}$ & $\begin{array}{l}20: 4 \\
\text { wt } \%\end{array}$ \\
\hline $\begin{array}{l}\text { Control } \\
\text { EFAD }\end{array}$ & $\begin{array}{l}3 \\
3\end{array}$ & $\begin{array}{l}14.6 \pm 3.1 \\
44.9 \pm 0.8\end{array}$ & $\begin{array}{r}36.0 \pm 1.8 \\
1.7 \pm 0.6\end{array}$ & $\begin{array}{r}0.3 \pm 0.3 \\
13.1 \pm 1.0\end{array}$ & $\begin{array}{c}4.3 \pm 1.8 \\
0\end{array}$ \\
\hline $\begin{array}{l}\text { Chow-repleted: } \\
\text { High plasma glucose } \\
\text { Low plasma glucose }\end{array}$ & $\begin{array}{l}8 \\
7\end{array}$ & $\begin{array}{l}16.5 \pm 1.0 \\
18.9 \pm 1.5\end{array}$ & $\begin{array}{l}30.6 \pm 1.0 \\
26.7 \pm 0.3\end{array}$ & $\begin{array}{l}1.4 \pm 0.2 \\
1.8 \pm 0.1\end{array}$ & $\begin{array}{l}6.3 \pm 0.5 \\
7.4 \pm 0.6\end{array}$ \\
\hline
\end{tabular}

18:1(9) and $20: 3(5,8,11)$ are $(n-9)$ fatty acids, whereas $18: 2(9,12)$ and $20: 4(5,8,11,14)$ are $(n-6)$ fatty acids. EFAD = essential fatty acid-deficient. Values are reported as means \pm SEM

for LDS-treated control, EFAD, and control chow-repleted EFAD mice were determined. Groups were compared by the "rank-sum test for several samples" which uses a chi-square distribution [16].

\section{Results}

\section{Confirmation of EFA deficiency}

Table 1 shows serum fatty acid profiles for CD-1 mice on control and EFAD diets. The EFAD mice showed a marked deficiency of linoleate $(18: 2[9,12])$ and arachidonate $(20: 4[5,8,11,14])$ as well as increased levels of oleate (18:1[9]) and Mead acid $(20: 3[5,8,11])$. The ratio of Mead acid to arachidonate exceeded 0.4 (i. e., a biochemical definition of essential fatty acid deficiency) [17].

\section{Comparison of linoleate and control chow repletion}

Figure 1 shows the relative incidence and severity of diabetes in LDS-treated control, EFAD, linoleate-repleted EFAD, and control chow-repleted EFAD mice. The incidence of diabetes in control, EFAD, linoleate-repleted EFAD, and chow-repleted EFAD mice was $100 \%$, $0 \%, 86 \%$, and $100 \%$ respectively; the mean plasma glucose levels at the end of the experiment were $29.6 \mathrm{mmol} / \mathrm{l}$, $8.6 \mathrm{mmol} / 1,23.9 \mathrm{mmol} / \mathrm{l}$, and $23.2 \mathrm{mmol} / 1$ respectively [ANOVA, $\mathrm{F}(3,24)=30.2, p<0.0001]$. Because the incidence and severity of diabetes and insulitis in the two groups of repleted mice were essentially identical (paired comparison, $\mathrm{t}=0.3, \mathrm{df}=12, \mathrm{NS}$ ), we repleted EFAD mice by switching them to control chow in the subsequent study rather than give linoleate injections.

\section{Longitudinal repletion study}

Figure 2 shows the incidence and severity of diabetes in LDS-treated EFAD mice, control mice, or EFAD mice repleted with control chow; repleted mice were repleted $6 \mathrm{~h}$, 1 week, 2 weeks, 4 weeks, or 8 weeks after the last LDS injection. At the end of the experiment, the incidence of diabetes in control and EFAD mice was $100 \%$ and $0 \%$; the incidence in $6 \mathrm{~h}, 1$ week, 2 week, 4 week, and 8 week chow-repleted mice was $93 \%, 37 \%, 40 \%, 20 \%$, and $8 \%$ respectively. The mean plasma glucose levels for control, $6 \mathrm{~h}$-repleted, 1 week-repleted, 2 week-repleted, 4 weekrepleted, 8 week-repleted, and EFAD mice were

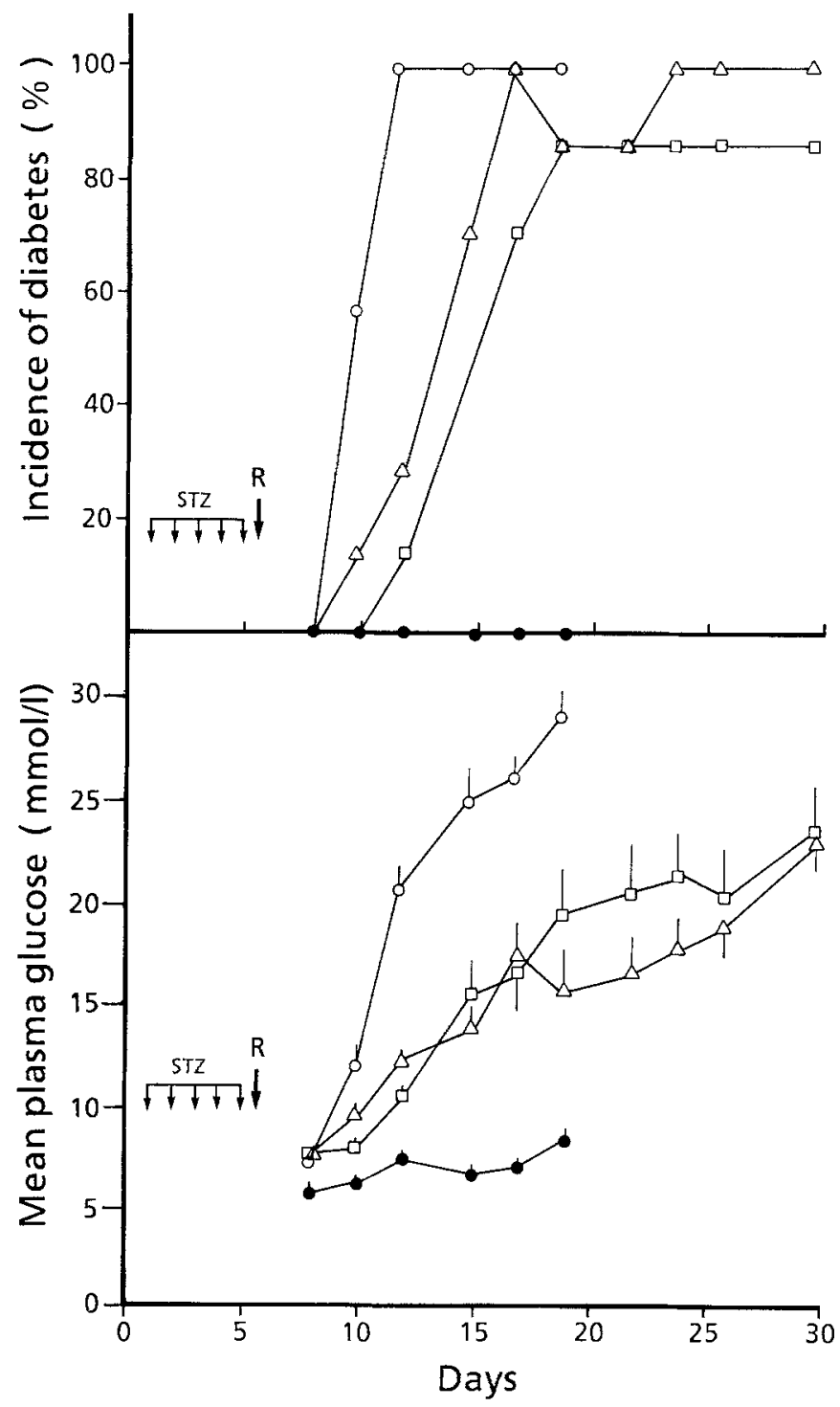

Fig. 1. Upper Daily incidence of diabetes [plasma glucose $>11.1 \mathrm{mmol} / \mathrm{l}]$ in low-dose streptozotocin-treated essential fatty acid deficient (EFAD) $(\bullet)$, control $(O)$, linoleate-repleted EFAD $(\square)$, and chow-repleted EFAD $(\triangle)$ mice. Lower Corresponding daily mean plasma glucose levels. Analysis of variance (ANOVA) was performed to compare means at the end of week 4. ANOVA $F(3,24)=30.2 ; p<0.0001$. Paired comparisons: Control vs EFAD: $\mathfrak{t}=12.3 ; \mathrm{df}=12, p<0.001$; linoleate-repleted EFAD vs chow-repleted EFAD: $\mathrm{t}=0.3$; $\mathrm{df}=12$, NS. STZ = streptozotocin; $\mathrm{R}=$ repletion 


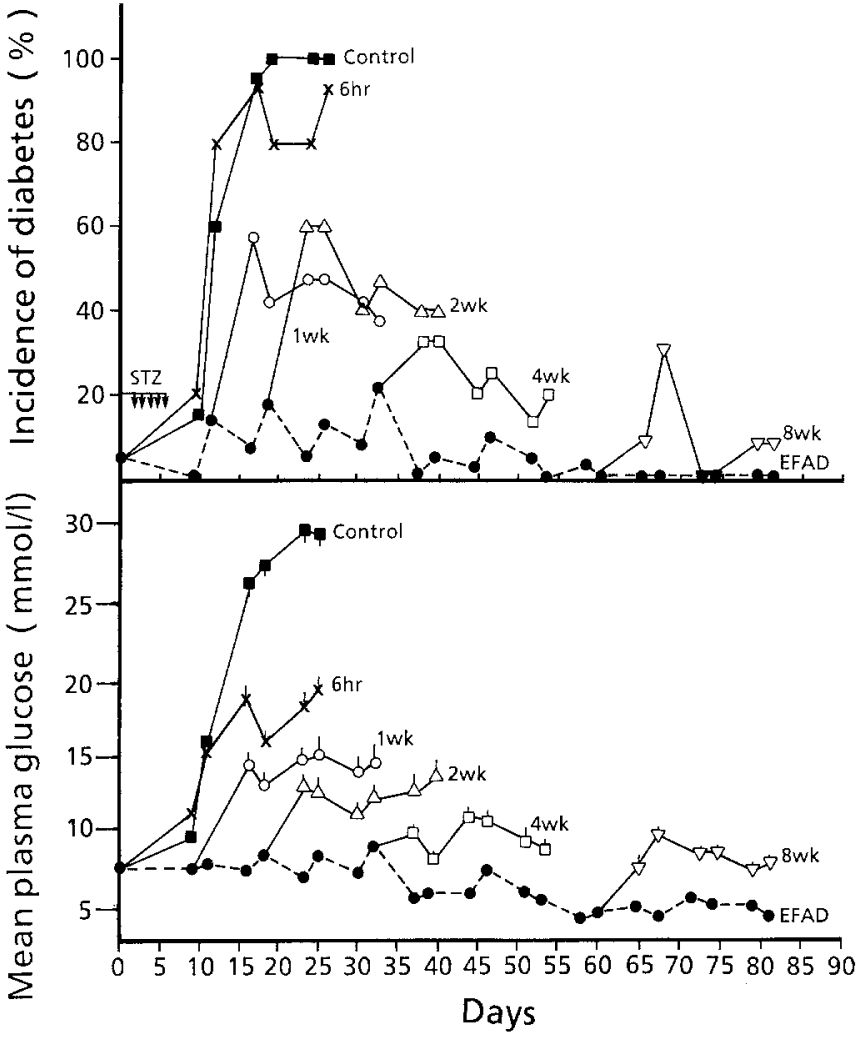

Fig. 2. Upper Daily incidence of diabetes in low-dose streptozotocin-treated essential fatty acid deficient (EFAD) $(\bullet, n=15)$, control $(\boldsymbol{\square}, n=20)$, as well as $6 \mathrm{~h}(\mathrm{X}, n=15), 1$ week $(O, n=19)$, 2 week $(\triangle, n=15), 4$ week $(\square, n=15)$, and 8 week $(\nabla, n=13)$ chow-repleted EFAD CD-1 mice. Lower Corresponding daily mean plasma glucose levels. Analysis of variance (ANOVA) was performed to compare means at the end of week 4. ANOVA $\mathrm{F}(6,105)=22.8 ; p<0.0001$. [n. b. - At the beginning of the experiment, 120 EFAD mice were randomly assigned to cages of five mice each and these cages were randomly assigned to experimental groups. After each time interval, the 4 cages comprising each group were switched to the control diet. Therefore, during the duration of the experiment the EFAD " $n$ " decreased from 120 to 15 (five mice in the non-repleted EFAD group died). Of the 120 EFAD mice, five became permanently diabetic while on the EFAD diet; these were excluded from the repletion portion of the study because it would not be possible to evaluate the diabetogenic effect of EFA repletion in mice that were already diabetic. These mice are included in this figure as EFAD mice until the time that there assigned cages were repleted at which time they were dropped from the study

$30.2 \mathrm{mmol} / \mathrm{l}, \quad 19.4 \mathrm{mmol} / \mathrm{l}, \quad 14.8 \mathrm{mmol} / \mathrm{h}, \quad 13.7 \mathrm{mmol} / \mathrm{l}$, $9.0 \mathrm{mmol} / 1,7.8 \mathrm{mmol} / 1$, and $4.2 \mathrm{mmol} / 1$ respectively at the end of the experiment [ANOVA, $\mathrm{F}(6,105)=22.8$, $p<0.0001]$. Therefore, there appears to be a brief window of susceptibility during which EFA repletion will initiate an autoimmune response and cause diabetes in LDStreated EFAD mice.

Histological evaluation of pancreata revealed highgrade insulitis and/or high-grade Beta-cell degranulation in control chow-fed LDS-treated mice; pancreata of LDStreated EFAD mice showed minimal inflammation (often peri-ductal) and a relative preservation of Beta-cell granulation. Chow-repleted, LDS-treated EFAD mice showed intermediate histological patterns; in general, "early repletion" resulted in relatively high-grade lesions while "late repletion" resulted in a relative sparing from
Beta-cell damage and inflammation. Composite insulitis/degranulation scores (mean $\pm \mathrm{SEM}$ ) for control, 6 h-repleted, 1 week-repleted, 2 week-repleted, 4 weekrepleted, 8 week-repleted, and EFAD groups were $6.1 \pm 0.36, \quad 5.3 \pm 0.49, \quad 4.1 \pm 0.53, \quad 2.8 \pm 0.62, \quad 2.9 \pm 0.45$, $2.5 \pm 0.58$, and $2.2 \pm 0.43$ respectively $\left[\mathrm{Chi}^{2}(\mathrm{df}=6)=48.9\right.$, $p<0.001$, rank-sum test].

\section{Plasma fatty acid profiles in repleted mice}

Because some "early" repleted mice became severely diabetic and other apparently identical mice remained normoglycaemic, fatty acid profiles were examined in the $6 \mathrm{~h}$ and 1 week repleted mice with the lowest and the highest plasma glucose levels (Table 1). Mean levels of $18: 1,18: 2,20: 3$, and 20:4 were almost identical for these two groups suggesting that severely diabetic mice were not "better repleted" than non-diabetic mice. In all instances, EFA repletion ameliorated dermatitis and, as noted during autopsies, grossly reversed hepatic fatty change.

\section{Length of protective effect}

In our previous study, mice were killed 1 month after the last LDS injection [8]. Therefore, the length of the protective effect of EFA deficiency is unknown. In the present study, the incidence of diabetes in LDS-treated EFAD mice was $0 \%$ at the end of 12 weeks. Although we had planned to follow-up a group of LDS-treated CD-1 mice indefinitely, we terminated this experiment because the mice developed severe necrotizing dermatitis.

Furthermore, this study was unnecessary because we have shown that EFA repletion beyond the brief window of susceptibility does not precipitate diabetes.

\section{Discussion}

The presence of an autoimmune component in the LDS mouse model is demonstrated, not only by lymphocytic infiltration into the islets and the thymic dependency of the diabetic state [18], but also by the ability to ameliorate or prevent diabetes with immunosuppression. Immunosuppressive regimens directed primarily at lymphocytes are only partially protective. For instance, whole-body irradiation alone only decreased the severity of the diabetes [19]. Likewise, pre-treatment with antibodies to L3T4 + lymphocytes [20], Lyt 2 + lymphocytes [20], or Thy-1 + lymphocytes [21] or with anti-lymphocytic serum [22] are only partially protective. Several new immunosuppressive drugs with poorly understood mechanisms of action are also partially protective [23-25].

Recently, the pivotal role of macrophages in the pathogenesis of diabetes in man and experimental animals has been recognized [5, 26-27]. Electron microscopy reveals that macrophages comprise the earliest insular infiltrate in the LDS mouse model [28]. Oschilewski et al. [21] have shown that an anti-macrophage treatment (i.e. silica injections) more effectively inhibited the onset of diabetes in LDS-treated mice than an anti- pan T-cell treatment 
(i.e. administration of a monoclonal antibody to Thy-1). We have previously shown that treatment (beginning $5 \mathrm{~h}$ after the last LDS injection) with desferrioxamine, a potent hydroxyl radical inhibitor, has a marked protective effect against LDS-induced diabetes and insulitis [13]. Our findings strongly implicate the macrophage as playing a critical role in initiating Beta-cell destruction because free radical scavengers should have little direct effect on lymphocytes, inflammatory cells not known to produce cytotoxic free radicals. Likewise, inhibitors of cyclooxygenase and lipoxygenase pathways also suppress the onset of diabetes in mice after LDS [29]. This effect is almost certainly mediated through suppression of macrophage eicosanoid production; lymphocytes produce, at best, minimal amounts of these products relative to macrophages [30].

We hypothesize that the induction of diabetes with multiple low doses of streptozotocin requires at least five distinct steps: 1) induction of LDS-induced neoantigens, 2) influx of activated macrophages into the damaged islet - probably amplifying the damage by free radical production and/or cytokine release, 3) processing and presentation of the Beta-cell neoantigens by the activated macrophages, 4) activation of $T$ helper cells, and 5) infiltration by cytotoxic $T$ cells.

It is clear that LDS causes Beta-cell damage prior to any specific (i.e. adaptive) immune response because mild glucose intolerance actually precedes the insulitis. We believe that the insulitis is a result of the recognition of LDSinduced Beta-cell neoantigens by the adaptive immune system. This is suggested by the observation that islet isografts performed only 2 weeks after the first LDS treatment do not even incite an inflammatory response in mice with active insulitis [31; Wright and Lacy - unpublished observation]; however, islets treated with LDS in vitro prior to isotransplantation are destroyed by insulitis [32]. Whether this LDS-induced modification is due to the effects of DNA damage, retroviruses, or some other mechanism is unknown. Even though the nature of this neoantigen is ill-defined, EFA deficiency clearly does not prevent its formation since EFA repletion shortly after LDS precipitates insulitis and causes diabetes.

We believe that the protective effect of EFA deficiency probably acts at the level of the macrophage. A "single cell insulitis" (i.e. infiltration by activated macrophages) prior to the insulitis in LDS-treated mice has been reported by Kolb's laboratory [28]. There is strong evidence that EFA deficiency inhibits the influx of leucocytes in response to inflammatory stimuli $[33,34]$; EFA deficiency is known to markedly inhibit leucotriene B4 production [33]. It seems likely that EFA deficiency might prevent or lessen this "single-cell insulitis". If so, this could explain our observation that EFA repletion shortly after LDS treatment results in a high incidence of severe diabetes but that repletion 1 or 2 months after LDS does not. Islets are known to be exquisitely susceptible to free radical damage, in part, because they possess low levels of free radical scavenging enzymes [35-37]. Therefore, it seems likely that the initial LDS damage is amplified by the influx of activated macrophages. These activated macrophages would release free radicals causing more Beta-cell damage which would attract more activated macrophages re- sulting in a cascade effect. This amplification scheme could also explain why the hydroxyl scavenger desferrioxamine is highly protective against LDS-induced insulitis and diabetes [13]. In addition, the activated macrophages would also release monokines such as interleukin-1 and tumour necrosis factor which have also been reported to be cytotoxic to islets $[26,27,38]$; these could further amplify Beta-cell damage and promote a cascade effect.

Because EFAD macrophages lack arachidonic acid to be cycled through the cyclooxygenase and lipoxygenase pathways, it is possible that the protective effect is due to the relative inability of the EFAD macrophages to produce active eicosanoids. This concept is supported by the observation that the dual cyclooxygenase/lipoxygenase inhibitors BW755C has a protective effect in the LDS model [29]. We are currently testing selected "broad-spectrum" and "narrow-spectrum" inhibitors of eicosanoid synthesis for a protective effect in the LDS mouse model.

We cannot rule out entirely that other nutritional differences between the control diet and the EFAD diet contribute to the protective effect of EFA deficiency. However, any synergistic protective effect would have to be relatively insignificant because repletion of LDS-treated EFAD mice with the pure linoleate was as diabetogenic as repletion with control chow.

Acknowledgements. This work was supported by grants from the Canadian Diabetes Association and the Izaak Walton Killam Children's Hospital. The authors would like to thank Dr. M. Spence for helpful suggestions, Ms. G. Keddy for performing fatty acid measurements, the histology laboratory at the IWK Children's Hospital for processing tissue sections, Ms. M.Larlham for administrative support, and Ms. V. Jennings for secretarial assistance.

\section{References}

1. Wilson GL, Leiter EH (1990) Streptozotocin interactions with pancreatic B cells and the induction of insulin-dependent diabetes. Curr Top Microbiol Immunol 156: 27-54

2. Like AA, Rossini AA (1976) Streptozotocin-induced pancreatic insulitis: new model of diabetes mellitus. Science 193:415-417

3. Kiesel U, Falkenberg FW, Kolb H (1983) Genetic control of lowdose streptozotocin-induced autoimmune diabetes in mice. I Immunol 130: 1719-1722

4. Wolf J, Lilly F, Shin S (1984) The influence of genetic background on the susceptibility of inbred mice to streptozotocin-induced diabetes. Diabetes 33: 567-571

5. Kolb H (1987) Mouse models of insulin dependent diabetes mellitus: low-dose streptozotocin-induced diabetes and nonobese diabetic (NOD) mice. Diab Metab Rev 3: 751-778

6. Appel MC, Rossini AA, Williams RM, Like AA (1978) Viral studies in streptozotocin-induced pancreatic insulitis. Diabetologia 15: $327-336$

7. Like AA, Appel MC, Williams RM, Rossini AA (1978) Streptozotocin-induced pancreatic insulitis in mice: morphologic and physiologic studies. Lab Invest 38: 470-486

8. Wright JR Jr, Lefkowith JB, Schreiner G, Lacy PE (1988) Essential fatty acid deficiency prevents multiple low-dose streptozotocin-induced diabetes in CD-1 mice. Proc Natl Acad Sci USA 85: 6137-6141

9. Schreiner G, Rossini A, Mordes J et al. (1988) Essential fatty acid deficiency inhibits the development of diabetes in rats. Diabetes 37 [Suppl 1]: 80A (Abstract) 
10. Lenrow D, Luketich J, Naji A, Barker C (1989) Immune modulation of the $\mathrm{BB}$ rats by essential fatty acid deficient (EFAD) diet. Diabetes 38 [Suppl 2]: 74A (Abstract)

11. Lefkowith J, Schreiner G, Cormier J et al. (1990) Prevention of diabetes in the BB rat by essential fatty acid deficiency: relationship between physiological and biochemical changes. J Exp Med 171: 729-743

12. Wright JR Jr, Sennhouser DA, Yates AJ, Sharma HM, Thibert $P$ (1983) Spontaneous thyroiditis in BB Wistar rats. Vet Pathol 20: $522-530$

13. Mendola J, Wright JR Jr, Lacy PE (1989) Oxygen free-radical scavengers and immune destruction of murine islets in allograft rejection and multiple low-dose streptozotocin-induced insulitis. Diabetes 38: 379-385

14. Moser HW, Moser AB (1990) Measurement of saturated very long chain fatty acids in plasma. In: Hommes FA (ed) Techniques in diagnostic human biochemical genetics: a laboratory manual. Wiley-Liss, NY, pp 177-191

15. Thomas SE, Byers DM, Palmer FBStC, Spence MW, Cook HW (1990) Incorporation of polyunsaturated fatty acids into plasmalogens, compared to other phospholipids of cultured glioma cells, is more dependent on chain length than on selectivity between (n-3) and (n-6) families. Biochim Biophys Acta 1044: 349356

16. Dixon WJ, Massey FJ (1969) Introduction to statistical analysis, 3rd edn. McGraw-Hill, New York, pp 344-345

17. Holman R (1960) The ratio of trienoic:tetraenoic acids in tissue lipids as a measure of essential fatty acid requirement. J Nutr 70 : 405-410

18. Nakamura M, Nagafuchi S, Yamaguchi K, Takaki R (1984) The role of thymic immunity and insulitis in the development of streptozotocin-induced diabetes in mice. Diabetes 33: 894-900

19. Nedergaard M, Egeberg J, Kromann H (1983) Irradiation protects against pancreatic islet degeneration and hyperglycaemia following streptozotocin treatment of mice. Diabetologia 24 : 382-386

20. Herold KC, Montag AG, Fitch FW (1987) Treatment with antiT-lymphocyte antibodies prevents induction of insulitis in mice given multiple doses of streptozocin. Diabetes 36: 796-801

21. Oschilewski M, Schwab E, Kiesel U et al. (1986) Administration of silica or monoclonal antibody to Thy-1 prevents low-dose streptozotocin-induced diabetes in mice. Immunol Let 12: 289 294

22. Rossini AA, Williams RM, Appel MC, Like AA (1978) Complete protection from low-dose streptozotocin-induced diabetes in mice. Nature 276: 183-184

23. Linn T, Volkmann A, Germann $\mathrm{H}$ et al. (1987) Ciamexon in the low dose streptozotocin-induced diabetes in mice. Diab Res 6: 113-117

24. Kolb H, Oschilewski M, Oschilewski U et al. (1987) Analysis of 22 immunomodulatory substances for efficacy in low-dose streptozotocin-induced diabetes. Diab Res 6:21-27

25. Iwakiri R, Nagafuchi S (1989) Inhibition of streptozotocininduced insulitis and diabetes with lobenzarit in CD-1 mice. Diabetes 38: 558-561
26. Mandrup-Poulsen T (1988) On the pathogenesis of insulin-dependent diabetes. Dan Med Bull 35:438-460

27. Nerup J, Mandrup-Poulsen T, Mølvig J, Helqvist S, Wogensen L, Egeberg J (1988) Mechanism of pancreatic beta cell destruction in type I diabetes. A hypothetical model. Diab Care 11 [Suppl 1]: 16-23

28. Kolb-Bachofen V, Epstein S, Kiesel U, Kolb H (1988) Low-dose streptozotocin-induced diabetes in mice: electron microscopy reveals single cell insulitis before diabetes onset. Diabetes 37 : 21-27

29. Kiesel U, Epstein S, Kolb-Bachofen V (1987) Macrophage directed immune intervention suppresses the development of experimental diabetes. Diabetologia 30:539A (Abstract)

30. Higgs GA (1986) The role of eicosanoids in inflammation. Prog Lipid Res 25: 555-561

31. Andersson A (1979) Islet transplantation normalizes hyperglycaemia caused by streptozotocin-induced insulitis: experiments in mice. Lancet I: 581-584

32. Weide LG, Lacy P (1991) Low-dose streptozotocin-induced autoimmune diabetes in islet transplantation model. Diabetes 40: $1157-1162$

33. Lefkowith JB (1988) Essential fatty acid deficiency inhibits the in vivo generation of leukotriene B4 and suppresses levels of resident and elicited leukocytes in acute inflammation. J Immunol 140: $228-233$

34. Schreiner GF, Rovin B, Lefkowith JB (1989) The anti-inflammatory effects of essential fatty acid deficiency in experimental glomerulonephritis. The modulation of macrophage migration and eicosanoid metabolism. J Immunol 143: 3192-3199

35. Grankvist K, Marklund SL, Taljedal I-B (1981) CuZn-superoxide dismutase, Mn-superoxide dismutase, catalase, and glutathione peroxidase in pancreatic islets and other tissues in the mouse. Biochem J 199: 393-398

36. Asayama K, Burr IM (1985) Rat superoxide dismutases. Purification, labeling, immunoassay, and tissue concentration. J Biol Chem 260: 2212-2217

37. Malaisse WJ, Malaisse-Lagae F, Sener A, Pipeleers DG (1982) Determinants of the selective toxicity of alloxan to the pancreatic B cell. Proc Natl Acad Sci USA 79: 927-930

38. Pukel C, Baquerizo H, Rabinovitch A (1988) Destruction of rat islet cell monolayers by cytokines. Synergistic interactions of interferon- $\gamma$, tumor necrosis factor, lymphotoxin, and interleukin-1. Diabetes 37: 133-136

Received: 11 April 1991

and in revised form: 25 June 1991

Dr. J. R. Wright, Jr.

Department of Pathology

IWK Hospital for Children

5850 University Avenue

Halifax, Nova Scotia B3J 3G9

Canada 